\title{
Infectious diseases linked to cross-contamination of flexible endoscopes
}

Authors

Institutions
Nikki Kenters ${ }^{1}$, Elisabeth G. W. Huijskens ${ }^{2}$, Corianne Meier $^{3}$, Andreas Voss ${ }^{4,5}$

Albert Schweitzer Hospital, Department of Infection Prevention and Control, Dordrecht, Netherlands

${ }^{2}$ Albert Schweitzer Hospital, Department of Medical Microbiology, Dordrecht, Netherlands

Rivierenland Hospital, Department of Infection Prevention and Control, Tiel, Netherlands

${ }^{4}$ Canisius-Wilhelmina Hospital, Department of Medical Microbiology, Nijmegen, Netherlands

Radboud University Medical Centre, Nijmegen, NL
Bibliography

Dol http://dx.doi.org/

10.1055/s-0034-1392099

Published online: 19.6.2015

Endosc Int Open 2015; 03:

E259-E265

(c) Georg Thieme Verlag KG

Stuttgart $\cdot$ New York

E-ISSN 2196-9736

\section{Corresponding author:}

\section{Prof. Andreas Voss}

Canisius-Wilhelmina Hospital, Department of Medical

Microbiology

P.O. Box 9015

Nijmegen

Netherlands

Fax: +31243657516

vossandreas@gmail.com

andreas.voss@radboudumc.nl
Flexible endoscopes are widely used to examine, diagnose, and treat medical disorders. While the risk of endoscopy-related transmission of infection is estimated to be very low, more health care-associated infections are related to contaminated endoscopes than to any other medical device. Flexible endoscopes can get highly contaminated with microorganisms, secretions and blood during use. The narrow lumens and multiple internal channels make the cleaning of flexible endoscopes a complex and difficult task.

\section{Introduction}

$\nabla$

Flexible endoscopes are widely used to examine, diagnose, and treat medical disorders. Although the risk of endoscopy-related transmission of infection is estimated to be very low, more health care-associated infections are related to contaminated endoscopes than to any other medical device. Flexible endoscopes can get highly contaminated with microorganisms, secretions, and blood during use. The narrow lumens and multiple internal channels make the cleaning of flexible endoscopes a complex and difficult task. Bacteria are able to form biofilms on the inner channel surfaces, which can contribute to failure in the reprocessing of endoscopes [1]. Therefore, standardizing guidelines for cleaning and disinfection is important. Several federal agencies, such as the Centers for Disease Control and Prevention (CDC), and professional organizations such as the American Society for Gastrointestinal Endoscopy (ASGE) and the European Society of Gastrointestinal Endoscopy (ESGE), have developed endoscope reprocessing guidelines. Most of the European recommendations are based on publications from the International Organization of Standardization, ISO 15883.

In general, endoscope reprocessing includes precleaning (at bedside), leak testing, manual cleaning, high-level disinfection, rinsing, drying, and
Despite the availability of international, national and local endoscope reprocessing guidelines, contamination and transmission of microorganisms continue to occur. These transmissions are mostly related to the use of defective equipment, endoscope reprocessing failures, and noncompliance with recommended guidelines. This article presents an overview of publications about case reports and outbreaks related to contamination of flexible endoscopes.

storage. An automated endoscope reprocessor (AER) could be used to perform leak testing, high-level disinfection, and to rinse the flexible endoscope. The US Food and Drug Administration has approved only one AER that eliminates the manual cleaning step.Still, manual cleaning before disinfection is necessary because flexible endoscopes can contain a high bio burden. Because post-marketing clinical data on the efficacy of the cleaning phase of the AER are limited, manual cleaning is still recommended $[4,5]$.

Lack of cleaning or failure during the cleaning process could lead to the survival of pathogens after disinfection, increasing the risk of cross-contamination between patients. In addition, bacteria that remain after insufficient reprocessing may form a biofilm inside the instruments.

A problem or outbreak due to a flexible endoscope can be detected in two ways. The first is a deviation in data on infections gathered through active surveillance in the hospital. If the same endoscope was used on two patients who have become infected, the device will can be cultured to confirmation colonization. The second way to detect an outbreak is through surveillance of endoscopes and AERs to ascertain bacterial growth, which should lead to screening of patients. When an endoscope, AER, or screened patients show growth of the same bacteria, typing should be performed to determine whether the cluster 
Table 1 Publications related to damaged or defective flexible endoscopes

\begin{tabular}{|c|c|c|c|c|c|c|}
\hline Reference & Origin & $\begin{array}{l}\text { Micro-organism(s) } \\
\text { (resistance) }\end{array}$ & Problem & $\begin{array}{l}\text { No. of patients } \\
\text { exposed (posi- } \\
\text { tive cultures) }\end{array}$ & $\begin{array}{l}\text { No. of infections } \\
\text { (type(s)) }\end{array}$ & Action taken \\
\hline [9] & Bronchoscope & $\begin{array}{l}\text { Pseudomonas } \\
\text { aeruginosa }\end{array}$ & $\begin{array}{l}\text { Several defects in the } \\
\text { different tubes and } \\
\text { bending section }\end{array}$ & $20(11)$ & $\begin{array}{l}2 \text { (sepsis, } \\
\text { pneumonia) }\end{array}$ & Preventive maintenance \\
\hline [10] & Bronchoscope & $\begin{array}{l}\text { Pseudomonas } \\
\text { aeruginosa }\end{array}$ & $\begin{array}{l}\text { Damaged internal channel } \\
\text { due to defective biopsy } \\
\text { forceps }\end{array}$ & $36(16)$ & $\begin{array}{l}4 \text { (pneumonia, } \\
\text { bronchitis) }\end{array}$ & $\begin{array}{l}\text { Replacement of chan- } \\
\text { nels; use of } \\
\text { disposable biopsy for- } \\
\text { ceps }\end{array}$ \\
\hline [11] & Bronchoscope & $\begin{array}{l}\text { Pseudomonas } \\
\text { aeruginosa }\end{array}$ & Loose biopsy-port cap & 414 & $\begin{array}{l}32 \text { (respiratory } \\
\text { tract and blood- } \\
\text { stream infections) }\end{array}$ & $\begin{array}{l}\text { Bronchoscopes removed } \\
\text { from service }\end{array}$ \\
\hline [12] & Bronchoscope & $\begin{array}{l}\text { Pseudomonas } \\
\text { aeruginosa and } \\
\text { Serratia marcescens }\end{array}$ & Loose biopsy-port cap & $\begin{array}{l}\text { Not mentioned } \\
\text { (20) }\end{array}$ & 1 (pneumonia) & $\begin{array}{l}\text { Manufacturer initiated } \\
\text { recall of defective } \\
\text { bronchoscopes. }\end{array}$ \\
\hline [14] & Bronchoscope & $\begin{array}{l}\text { Mycobacterium } \\
\text { tuberculosis }\end{array}$ & $\begin{array}{l}\text { A hole in the external } \\
\text { sheath of the manoeuv- } \\
\text { rable tip }\end{array}$ & $19(10)$ & 4 (tuberculosis) & $\begin{array}{l}\text { Strict adherence to the } \\
\text { reprocessing protocol }\end{array}$ \\
\hline [13] & Bronchoscope & $\begin{array}{l}\text { Pseudomonas putida, } \\
\text { Pseudomonas } \\
\text { aeruginosa, } \\
\text { Stenotrophomonas } \\
\text { spp. }\end{array}$ & Loose biopsy port & $77(25)$ & 0 & $\begin{array}{l}\text { Recordkeeping for tight- } \\
\text { ness of the biopsy port; } \\
\text { standard operating } \\
\text { procedure for cleaning } \\
\text { and disinfection of } \\
\text { bronchoscopes; compe- } \\
\text { tency training; tracking } \\
\text { system for broncho- } \\
\text { scopes enhanced }\end{array}$ \\
\hline [15] & Bronchoscope & $\begin{array}{l}\text { Klebsiella pneumo- } \\
\text { niae, Proteus vulgaris, } \\
\text { Morganella morganii, } \\
\text { Proteus mirabilis }\end{array}$ & $\begin{array}{l}\text { Loose biopsy port; } \\
\text { Disinfectant did not reach } \\
\text { all areas. }\end{array}$ & $418(117)$ & 0 & $\begin{array}{l}\text { Removal and replace- } \\
\text { ment of plastic cap }\end{array}$ \\
\hline [16] & Bronchoscope & $\begin{array}{l}\text { Klebsiella pneumo- } \\
\text { niae (CRE) }\end{array}$ & $\begin{array}{l}\text { Defects in internal channel } \\
\text { surfaces }\end{array}$ & $\begin{array}{l}\text { Not mentioned } \\
\text { (6) }\end{array}$ & $\begin{array}{l}5 \text { (pneumonia, } \\
\text { sepsis) }\end{array}$ & $\begin{array}{l}\text { Repair of internal channel } \\
\text { surfaces }\end{array}$ \\
\hline
\end{tabular}

Abbreviation: CRE; Carbapenem-resistant enterobacteriaceae

(outbreak) is due to a contaminated endoscope or AER.

Incidence of carbapenem-resistant enterobacteriaceae (CRE) and other multidrug-resistant micro-organisms (MDRO) are increasing worldwide, and with them, the threat to public health because of limited treatment options. Given the linkage between contaminated flexible endoscopes and outbreaks of CRE and other MDROs, it is not surprising that they have been associated with higher patient morbidity and mortality [6].

Despite the availability of international, national, and local endoscope reprocessing guidelines, contamination and transmission of microorganisms continue [7]. Most such transmissions are related to use of defective equipment, endoscope reprocessing failures, and non-compliance with recommended guidelines [3, 8]. This article presents an overview of publications on case reports and outbreaks related to contamination of flexible endoscopes.

\section{Method}

The following search terms or combinations of terms were used to search in PubMed: endoscope, endoscope reprocessing, outbreak and infection. English-language studies published from 2000 on were included. In this review, the collected studies are divided into four categories: damaged or defective flexible endoscopes, failures during manual endoscope reprocessing, reprocessing failures where the disinfection step was carried out by an AER, and failure or malfunctioning of the AER.

\section{Results}

Thirty-two publications were included in this review. Of them, eight incidents involved damaged or defective flexible endoscopes, eight were related to failures during manual endoscope reprocessing, 11 reports related to reprocessing failures associated with disinfection carried out using an AER, and five reports documented failure or malfunctioning of the AER.

\section{Damaged or defective flexible endoscopes}

Eight publications were identified in which damaged bronchoscopes were involved in cross-contamination ( Table 1 ). Damage ranged from deteriorated equipment (e.g., a damaged internal channel) to a loose biopsy-port cap. Five incidents were due to contamination of the endoscope with Pseudomonas aeruginosa, including three publications that reported contamination of damaged bronchoscopes with both Pseudomonas aeruginosa and three other species (Serratia marcescens, Pseudomonas putida, Stenotrophomonas spp.) [9-13]. Contamination of an endoscope with Mycobacterium tuberculosis also was described [15], as was contamination of two endoscopes with Klebsiella pneumoniae, Proteus vulgaris, Proteus mirabillis, and Morganella morganii in 


\begin{tabular}{|c|c|c|c|c|c|c|}
\hline Reference & Origin & $\begin{array}{l}\text { Micro-organism(s) } \\
\text { (resistance) }\end{array}$ & Problem & $\begin{array}{l}\text { No. of patients } \\
\text { exposed (posi- } \\
\text { tive cultures) }\end{array}$ & $\begin{array}{l}\text { No. of infections } \\
\text { (type(s)) }\end{array}$ & Action taken \\
\hline [22] & Endoscope & $\begin{array}{l}\text { Klesbsiella spp. } \\
\text { (NDM-1) }\end{array}$ & $\begin{array}{l}\text { No guidelines for cleaning } \\
\text { video camera head; } \\
\text { no disposable plastic } \\
\text { camera sheaths }\end{array}$ & $\begin{array}{l}\text { Not mentioned } \\
\text { (12) }\end{array}$ & 3 (urosepsis) & $\begin{array}{l}\text { Standardized practice in } \\
\text { the use of camera sheath } \\
\text { and infection control } \\
\text { processes }\end{array}$ \\
\hline [17] & Cytoscope & $\begin{array}{l}\text { Pseudomonas } \\
\text { aeruginosa }\end{array}$ & $\begin{array}{l}\text { Incorrect disinfection } \\
\text { method }\end{array}$ & $\begin{array}{l}\text { Not mentioned } \\
\text { (7) }\end{array}$ & $\begin{array}{l}7 \text { (bloodstream, } \\
\text { urinary tract) }\end{array}$ & $\begin{array}{l}\text { Revision of cleaning and } \\
\text { disinfection processes }\end{array}$ \\
\hline [18] & Ureteroscope & $\begin{array}{l}\text { Pseudomonas } \\
\text { aeruginosa }\end{array}$ & $\begin{array}{l}\text { Inadequate cleaning and } \\
\text { disinfection }\end{array}$ & $81(12)$ & $\begin{array}{l}12 \text { (bloodstream, } \\
\text { urinary tract) }\end{array}$ & $\begin{array}{l}\text { Strict adherence to } \\
\text { reprocessing procedures; } \\
\text { sustained education }\end{array}$ \\
\hline [19] & Bronchoscope & $\begin{array}{l}\text { Pseudomonas } \\
\text { aeruginosa }\end{array}$ & $\begin{array}{l}\text { Inadequate cleaning and } \\
\text { disinfection during the } \\
\text { weekend }\end{array}$ & $\begin{array}{l}\text { Not mentioned } \\
\text { (17) }\end{array}$ & $\begin{array}{l}17 \text { (respiratory } \\
\text { tract, blood- } \\
\text { stream, urinary } \\
\text { tract, pressure ul- } \\
\text { cer, surgical site) }\end{array}$ & $\begin{array}{l}\text { Strict adherence to } \\
\text { reprocessing procedures } \\
\text { and maintenance }\end{array}$ \\
\hline [20] & Bronchoscope & $\begin{array}{l}\text { Pseudomonas } \\
\text { aeruginosa and } \\
\text { Serratia marcescens }\end{array}$ & $\begin{array}{l}\text { Inappropriate measures } \\
\text { used for cleaning and } \\
\text { disinfection }\end{array}$ & $\begin{array}{l}\text { Not mentioned } \\
(41)\end{array}$ & 0 & $\begin{array}{l}\text { Revision of infection } \\
\text { control measures }\end{array}$ \\
\hline [21] & Duodenoscope & $\begin{array}{l}\text { Pseudomonas } \\
\text { aeruginosa }\end{array}$ & $\begin{array}{l}\text { Inadequate high-level } \\
\text { disinfection }\end{array}$ & $12(5)$ & 4 (cholangitis) & $\begin{array}{l}\text { Awareness for oppor- } \\
\text { tunistic infections }\end{array}$ \\
\hline [23] & Gastroscope & Trichosporon & $\begin{array}{l}\text { Strain resistant to } \\
\text { disinfectant } \\
\text { Biopsy forceps not } \\
\text { sterilized }\end{array}$ & $1(1)$ & 1 (esophagitis) & Not mentioned \\
\hline [24] & Ureteroscope & $\begin{array}{l}\text { Enterobacter cloacae } \\
\text { (Ertapenem) }\end{array}$ & $\begin{array}{l}\text { Disinfection failure of a } \\
\text { contaminated uretero- } \\
\text { scope }\end{array}$ & $\begin{array}{l}\text { Not mentioned } \\
\text { (15) }\end{array}$ & $\begin{array}{l}15 \text { (flank pain, fe- } \\
\text { ver, frequency, } \\
\text { rurbid urine) }\end{array}$ & $\begin{array}{l}\text { Implementation of a } \\
\text { revised disinfection } \\
\text { protocol }\end{array}$ \\
\hline
\end{tabular}

Abbreviations: AER; automatic endoscope reprocessor; NDM-1; New Delhi-metallo-bèta-lactamase

another publication , and contamination of a bronchoscope with a CRE K. pneumoniae in another report [17].

\section{Failures during manual endoscope reprocessing}

- Table 2 lists eight publications in which failures during endoscope reprocessing were reported. Problems ranged from inadequate use of equipment to non-compliance with endoscope reprocessing guidelines. Five out of eight publications described contamination with $P$. aeruginosa, including one publication that reported contamination with both $P$. aeruginosa and Serratia marcescens $[18-22]$. One study described contamination with $K$. pneumoniae (New Delhi Metallo-beta-lactamase (NDM)-positive) [23]. In two other studies, contamination with, Trichosporon spp. and Enterobacter cloacae (resistant to Ertapenem) was described $[26,27]$.

Reprocessing failures related to disinfection with an AER - Table 3 lists 11 publications in which failures during endoscope reprocessing were described that involved disinfection carried out with an AER. In four of the studies, contamination of endoscopes was with $P$. aeruginosa [28 - 31]. In three other studies, involving a duodenoscope, contaminated was with $K$. pneumoniae (ESBL- and CRE-positive) [24,25,32]. The other two publications involving a duodenoscope described contamination with Escherichia coli (NDM- and CRE-positive) and Methylobacterium mesophillicum $[14,33]$. Two studies listed in $\bullet$ Table 3 also described contamination with Mycobacterium tuberculosis, Mycobacterium chelonae, and Methylbacterium mesophillicum [34,35]. Only three of the 11 studies involved failure of an AER.
Failures due to a defective or malfunctioning AER

Five publications that related problems with an AER are listed in - Table4. In three of the studies, endoscope contamination with Burkholderia cepacia, Pseudomonas aeruginosa, and Mycobacterium chelonae, respectively, due to a problem with the AER were described [36-38]. Two other publications reported malfunctioning AERs that did not lead to transmission of microorganisms $[39,40]$.

As shown in table 1, 2, 3 \& 4 contaminated endoscopes cause infections and may have contributed to the death of some patients. The most common infections are bloodstream (bacteraemia or sepsis), pneumonia and urinary tract infections.

\section{Discussion}

There is an assumption that the risk of cross-contamination is almost non-existent when flexible endoscopes are reprocessed in accordance with accepted guidelines [7]. Nevertheless, studies have found that, despite adherence to cleaning and disinfection guidelines, endoscopes can remain contaminated, leading to infections $[41,42]$. Defects, either during production or during use, such as a loose biopsy-port cap, can cause outbreaks or infections [11 -13]. Lack of maintenance also can lead to contamination of flexible endoscopes. Therefore, manufacturers recommend periodic maintenance to ensure that no defect occurs during the life cycle of a flexible endoscope. The CDC guidelines concur with this recommendation [2]. 
Table 3 Publications related to reprocessing failures where the disinfection step was carried out by an AER

\begin{tabular}{|c|c|c|c|c|c|c|}
\hline Reference & Origin & $\begin{array}{l}\text { Micro-organism(s) } \\
\text { (resistance) }\end{array}$ & Problem & $\begin{array}{l}\text { No. of patients } \\
\text { exposed (posi- } \\
\text { tive cultures) }\end{array}$ & $\begin{array}{l}\text { No. of infections } \\
\text { (type(s)) }\end{array}$ & Action taken \\
\hline [25] & Endoscope & $\begin{array}{l}\text { Pseudomonas aerugi- } \\
\text { nosa } \\
\text { (ESBL) }\end{array}$ & $\begin{array}{l}\text { Deviations from the } \\
\text { agreed processes (pre- } \\
\text { cleaning and drying pro- } \\
\text { cess) }\end{array}$ & $182(4)$ & 3 & $\begin{array}{l}\text { Strict adherence to } \\
\text { reprocessing procedures; } \\
\text { quarterly microbiological } \\
\text { testing }\end{array}$ \\
\hline [29] & Duodenoscope & $\begin{array}{l}\text { Klebsiella } \\
\text { pneumoniae } \\
\text { (CRE) }\end{array}$ & No optimal drying process & $17(7)$ & 2 (bloodstream) & $\begin{array}{l}\text { Revision of disinfection } \\
\text { processes; monthly } \\
\text { microbiological controls }\end{array}$ \\
\hline [30] & Duodenoscope & $\begin{array}{l}\text { Klebsiella pneumonia } \\
\text { (ESBL) }\end{array}$ & $\begin{array}{l}\text { Insufficient manual clean- } \\
\text { ing and drying before sto- } \\
\text { rage }\end{array}$ & $\begin{array}{l}\text { Not mentioned } \\
\text { (16) }\end{array}$ & $\begin{array}{l}12 \text { (bloodstream, } \\
\text { biliary tract) }\end{array}$ & $\begin{array}{l}\text { Strict adherence to } \\
\text { reprocessing procedures; } \\
\text { regular auditing }\end{array}$ \\
\hline [26] & Ureteroscope & $\begin{array}{l}\text { Pseudomonas } \\
\text { aeruginosa }\end{array}$ & $\begin{array}{l}\text { Contaminated water due } \\
\text { to failure in ultraviolet dis- } \\
\text { infection system }\end{array}$ & $\begin{array}{l}\text { Not mentioned } \\
\text { (10) }\end{array}$ & 10 (urinary tract) & $\begin{array}{l}\text { New water disinfection } \\
\text { system }\end{array}$ \\
\hline [27] & Bronchoscope & $\begin{array}{l}\text { Pseudomonas } \\
\text { aeruginosa }\end{array}$ & $\begin{array}{l}\text { No procedure for cleaning } \\
\text { and disinfecting broncho- } \\
\text { scope; no instruction for } \\
\text { use of AER }\end{array}$ & $\begin{array}{l}\text { Not mentioned } \\
\text { (11) }\end{array}$ & Not mentioned & $\begin{array}{l}\text { New reprocessing } \\
\text { procedure; sustained } \\
\text { education }\end{array}$ \\
\hline [34] & Bronchoscope & $\begin{array}{l}\text { Mycobacterium } \\
\text { chelonae and } \\
\text { Methylobacterium } \\
\text { mesophilicum }\end{array}$ & $\begin{array}{l}\text { Bronchoscope not adapted } \\
\text { to connection for final al- } \\
\text { cohol flush; improper ex- } \\
\text { ecution of 8-hour disinfec- } \\
\text { tion cycle }\end{array}$ & $\begin{array}{l}\text { Not mentioned } \\
(20)\end{array}$ & 0 & $\begin{array}{l}\text { Replacement of auto- } \\
\text { mated washer and disin- } \\
\text { fection unit; } \\
\text { quarterly maintenance } \\
\text { and surveillance cultures }\end{array}$ \\
\hline [35] & Bronchoscope & $\begin{array}{l}\text { Mycobacterium } \\
\text { tuberculosis }\end{array}$ & $\begin{array}{l}\text { Inadequate high-level dis- } \\
\text { infection; use of AER was } \\
\text { not approved for this } \\
\text { bronchoscope. }\end{array}$ & $11(2)$ & 0 & $\begin{array}{l}\text { Education and training } \\
\text { for health care providers, } \\
\text { staff and laboratory } \\
\text { workers }\end{array}$ \\
\hline [32] & Duodenoscope & $\begin{array}{l}\text { Escherichia coli } \\
\text { (NDM-1) }\end{array}$ & $\begin{array}{l}\text { Recommended reproces- } \\
\text { sing process inadequate. }\end{array}$ & $156(35)$ & 6 & Gas sterilization \\
\hline [33] & Duodenoscope & $\begin{array}{l}\text { Methylobacterium } \\
\text { mesophillicum }\end{array}$ & $\begin{array}{l}\text { Contaminated water used } \\
\text { to rinse inner channel. }\end{array}$ & $\begin{array}{l}\text { Not mentioned } \\
\text { (1) }\end{array}$ & 1 (bloodstream) & $\begin{array}{l}\text { Replacement of inner } \\
\text { channel sheath }\end{array}$ \\
\hline [31] & Duodenoscope & $\begin{array}{l}\text { Klebsiella } \\
\text { pneumoniae (CRE) }\end{array}$ & $\begin{array}{l}\text { Inadequate cleaning } \\
\text { technique }\end{array}$ & $53(10)$ & $\begin{array}{l}7 \text { (bloodstream, } \\
\text { pneumonia, } \\
\text { urinary tract) }\end{array}$ & $\begin{array}{l}\text { New reprocessing } \\
\text { procedure }\end{array}$ \\
\hline [28] & Bronchoscope & $\begin{array}{l}\text { Pseudomonas } \\
\text { aeruginosa }\end{array}$ & $\begin{array}{l}\text { Detergent tank of AER } \\
\text { Contaminated; } \\
\text { inappropriate } \\
\text { disinfection procedure }\end{array}$ & $\begin{array}{l}\text { Not mentioned } \\
\text { (7) }\end{array}$ & $\begin{array}{l}7 \text { (pneumonia, } \\
\text { bronchitis) }\end{array}$ & $\begin{array}{l}\text { Cleaning and } \\
\text { remodelling of the AER; } \\
\text { disinfection of } \\
\text { bronchoscopes }\end{array}$ \\
\hline
\end{tabular}

Abbreviations: AER; automatic endoscope reprocessor; ESBL; Extended-Spectrum Beta-Lactamase; CRE; Carbapenem-resistant enterobacteriaceae; NDM-1; New Delhimetallo-bèta-lactamase

Table 4 Publications related to failure due to a defective or malfunctioning AER

\begin{tabular}{|c|c|c|c|c|c|c|}
\hline Reference & Origin & $\begin{array}{l}\text { Micro-organism(s) } \\
\text { (resistance) }\end{array}$ & Problem & $\begin{array}{l}\text { No. of patients } \\
\text { exposed (posi- } \\
\text { tive cultures) }\end{array}$ & $\begin{array}{l}\text { No. of infections } \\
\text { (type(s)) }\end{array}$ & Action taken \\
\hline [36] & AER & Burkholderia cepacia & $\begin{array}{l}\text { No } 0.2 \mu \mathrm{m} \text { bacteria- } \\
\text { retentive filter }\end{array}$ & $\begin{array}{l}\text { Not mentioned } \\
\text { (3) }\end{array}$ & 0 & $\begin{array}{l}\text { Installation of bacteria } \\
\text { filter; microbiology } \\
\text { surveillance }\end{array}$ \\
\hline [37] & AER & $\begin{array}{l}\text { Mycobacterium } \\
\text { chelonae }\end{array}$ & Filtration system failure & $57(9)$ & 0 & Renewal of AER \\
\hline [39] & AER & None & $\begin{array}{l}\text { Pump for injecting disin- } \\
\text { fectant did not work; non- } \\
\text { functioning alarm system }\end{array}$ & $236(0)$ & 0 & Stop use of AER \\
\hline [40] & AER & None & No detergent & $72(0)$ & 0 & $\begin{array}{l}\text { Improve monitoring of } \\
\text { procedure; traceability of } \\
\text { cleaning process }\end{array}$ \\
\hline [38] & AER & $\begin{array}{l}\text { Pseudomonas } \\
\text { aeruginosa } \\
\text { (Imipenem) }\end{array}$ & $\begin{array}{l}\text { Faulty connection of } \\
\text { bronchoscope to } \\
\text { processor }\end{array}$ & $\begin{array}{l}\text { Not mentioned } \\
\text { (18) }\end{array}$ & $\begin{array}{l}3 \text { (pulmonary } \\
\text { infection) }\end{array}$ & $\begin{array}{l}\text { Monthly surveillance } \\
\text { cultures }\end{array}$ \\
\hline
\end{tabular}

Abbreviation: AER; automatic endoscope reprocessor 
Guidelines for reprocessing of flexible endoscopes are ineffective if not implemented and applied correctly $[11,20]$. Several studies have shown that non-compliance with reprocessing guidelines may lead to endoscope-related health care-associated infections $[7,8,43]$. Studies suggest that lack of education is one of the reasons that guidelines are not strictly followed. Staff assigned to reprocess flexible endoscopes should receive device-specific reprocessing training to ensure that they follow procedures for proper cleaning and high-level disinfection or sterilization. In addition, competency testing of staff responsible for reprocessing of flexible endoscopes should be implemented and only staffed deemed competent should be allowed to perform this task [3,44-46].

Periodic auditing of procedures followed for reprocessing should be carried out. The Clean-Trace adenosine triphospathe (ATP) water test, which is performed on manually cleaned endoscopes, can be considered as an auditing tool $[47,48]$. It is a rapid and practical way to check the cleanliness of endoscopes immediately after they have been manually cleaned. The test measures ATP levels, which are present in microorganisms and human cells; levels up to 200 relative light units (RLUs) are considered acceptable. As described in Alfa et al [47], the elevator guide-wire channel is more often found contaminated in duodenoscopes than in colonoscopes. The problems with duodenoscopes documented in the literature identified in this review were often related to this channel ( Table 2 and $\bullet$ Table 3 ). Therefore, incorporating an ATP test into the auditing procedure would help detect and prevent cross-contamination of duodenoscopes. In addition, health care workers involved in reprocessing should be made aware of the patient safety issues that can arise from any oversights and inaccuracies in their work.

AERs improve standardization of the reprocessing steps, reduce personnel exposure to high-level disinfectants, infectious material and lower the possibility of human errors [2]. They reduce the amount of hands-on work and provide documentation of each cleaning cycle [43]. Despite their obvious advantages, the use of AERs is not specifically mentioned in various guidelines and recommendations $[4,8,49]$. In addition, failures of AERs are reported and linked to infection outbreaks or colonization [2]. Furthermore, the function of the water filtration system in AERs might not be reliable in providing bacteria-free water [50]. In view of their advantages, as well as the fact that they can be a potential source of contamination, AERs should be intergraded in endoscope reprocessing guidelines. There is no evidence available that manual disinfection of endoscopes increases the risk of microorganisms transmission compared to using an AER. However, manual reprocessing cannot be standardized and validated, and are prone to human error.

As with the use of AER, not all guidelines recommend routine microbiological testing of flexible endoscopes and AERs for quality assurance $[2,51]$. Testing remains controversial in the absence of a standardized procedure for microbiological testing, frequency of testing, and interpretation of results. Also problematic is the lack of a threshold beyond which colonization of an endoscope by different bacteria becomes problematic. In the absence of guidelines, health care facilities have created their own procedures for microbiological testing, thus potentiating the risk of inadequate testing. An outbreak already has been documented that is believed to be a result of contamination of flexible endoscopes due to inadequate testing procedures, which was overlooked [25]. Standardized routine microbiological testing should be implemented based on existing guidelines, as has been done with German, Dutch, and Australian guidelines [52 - 54].

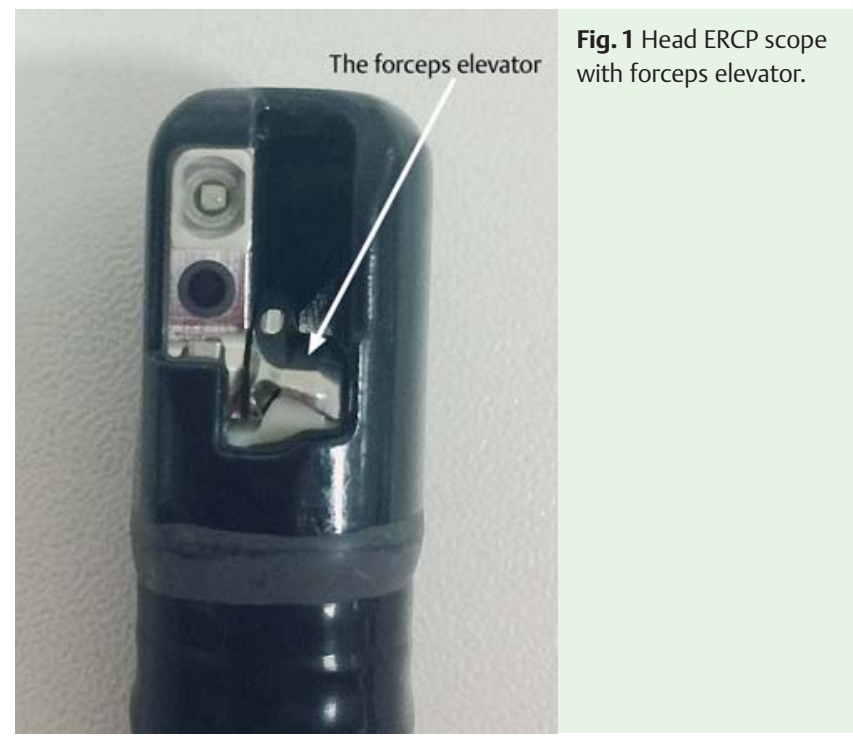

In addition, given the recent CRE outbreaks, attention needs to be given to strict adherence to instructions for brushing the area around, near, and behind the forceps elevator, which is located at the distal end of the duodenoscope. That part is difficult to clean because of its design, which consists of a small tube that includes a small mobile metal piece called the elevator ( $\bullet$ Fig. 1 ). The "extra" manual step of brushing is needed to prevent possible transmissions of CRE and of other multidrug-resistant organisms during flexible endoscopy. When confronted with an outbreak of CRE due to contaminated flexible endoscopes, the use of ethylene oxide (EtO) sterilization for reprocessing is worth considering [6].

Because not all incidences are reported or published, the studies described here probably represent just a fraction of the total number of reprocessing failures. In a recent publication, Dirlam Langlay et al. [55] summarized reprocessing lapses that occurred but were not documented in the published literature over a 7 year period in North America. Based on media reports and related sources, the authors found 27 lapses, whereas only one case was described in a peer-reviewed article.

Despite the fact that colonoscopy is the gastrointestinal endoscopic examination most frequently performed worldwide, no outbreaks related to the procedure have been described in the peer-reviewed literature. A review by Morris et al. [56] describes no transmission with blood-borne viruses either. The risk of patient-to-patient transmission of blood-borne viruses seems to be low, even with inadequate decontamination procedures. Only one case of probable hepatitis B transmission and two cases of probable hepatitis $C$ transmission were described. No cases of HIV transmission at endoscopy were found in literature. The lack of publications in peer-reviewed literature gives the false perception that reprocessing failure is a rare occurrence. Mandatory reporting of lapses to a national registry would give a better overview of incidents and facilitate more in-depth investigations, leading to better guidelines.

In conclusion, mandatory competency training and periodic auditing are necessary to ensure the quality of reprocessing of flexible endoscopes. Early detection of contamination would be easier if standardized periodic microbiological testing were included in the guidelines. Because AERs are often used for flexible endoscope reprocessing, they should be included in the guidelines. Periodic maintenance of flexible endoscopes and AERs should al- 
ways be carried out as the manufacturer advises. Mandatory reporting of lapses would provide a broader perspective on the worldwide incidence of cross-contamination of flexible endoscopes.

\section{Competing interests: None}

\section{References}

1 Kovaleva J, Peters FT, van der Mei HC et al. Transmission of infection by flexible gastrointestinal endoscopy and bronchoscopy. Clin Microbiol Rev 2013; 26: 231-254

2 Rutala WA, Weber DJ. Committee HICPA. Guidedline for disinfection and sterilization in healthcare facilities. Atlanta, GA: CDC; 2008

3 Committee AQAIE, Petersen BT, Chennat J et al. Multisociety guideline on reprocessing flexible gastrointestinal endoscopes: 2011. Gastrointest Endosc 2011; 73: 1075-1084

4 Beilenhoff U, Neumann CS, Rey JF et al. ESGE-ESGENA Guideline: cleaning and disinfection in gastrointestinal endoscopy. Endoscopy 2008; 40: 939-957

5 Committee AT, Pedrosa MC, Farraye FA et al. Minimizing occupational hazards in endoscopy: personal protective equipment, radiation safety, and ergonomics. Gastrointest Endosc 2010; 72: 227-235

6 Muscarella LF. Risk of transmission of carbapenem-resistant Enterobacteriaceae and related "superbugs" during gastrointestinal endoscopy. World J Gastrointest Endosc 2014; 6: 457 - 474

7 Nelson DB, Muscarella LF. Current issues in endoscope reprocessing and infection control during gastrointestinal endoscopy. World J Gastroenterol 2006; 12: 3953 -3964

8 Nelson DB, Jarvis WR, Rutala WA et al. Multi-society guideline for reprocessing flexible gastrointestinal endoscopes. Society for Healthcare Epidemiology of America. Infect Control Hosp Epidemiol 2003; 24: 532-537

9 DiazGranados CA, Jones MY, Kongphet-Tran T et al. Outbreak of Pseudomonas aeruginosa infection associated with contamination of a flexible bronchoscope. Infect Control Hosp Epidemiol 2009; 30: 550-555

10 Corne P, Godreuil S, Jean-Pierre $H$ et al. Unusual implication of biopsy forceps in outbreaks of Pseudomonas aeruginosa infections and pseudo-infections related to bronchoscopy. J Hosp Infect 2005; 61: 20-26

11 Srinivasan A, Wolfenden $L L$, Song $X$ et al. An outbreak of Pseudomonas aeruginosa infections associated with flexible bronchoscopes. N Engl J Med 2003; 348: $221-227$

12 Kirschke DL, Jones TF, Craig AS et al. Pseudomonas aeruginosa and Serratia marcescens contamination associated with a manufacturing defect in bronchoscopes. N Engl J Med 2003; 348: 214-220

13 Cosgrove SE, Ristaino P, Caston-Gaa A et al. Caveat emptor: the role of suboptimal bronchoscope repair practices by a third-party vendor in a pseudo-outbreak of pseudomonas in bronchoalveolar lavage specimens. Infect Control Hosp Epidemiol 2012; 33: 224-229

14 Imbert G, Seccia Y, La Scola B. Methylobacterium sp. bacteraemia due to a contaminated endoscope. J Hosp Infect 2005; 61: 268-270

15 Ramsey AH, Oemig TV, Davis JP et al. An outbreak of bronchoscopyrelated Mycobacterium tuberculosis infections due to lack of bronchoscope leak testing. Chest 2002; 121: 976-981

16 Cetre JC, Nicolle MC, Salord $H$ et al. Outbreaks of contaminated broncho-alveolar lavage related to intrinsically defective bronchoscopes. J Hosp Infect 2005; 61: 39-45

17 Zweigner J, Gastmeier P, Kola A et al. A carbapenem-resistant Klebsiella pneumoniae outbreak following bronchoscopy. Am J Infect Control 2014; 42: 936-937

18 Wendelboe AM, Baumbach J, Blossom DB et al. Outbreak of cystoscopy related infections with Pseudomonas aeruginosa: New Mexico, 2007. J Urol 2008; 180: 588-592; discussion 592

19 Kayabas U, Bayraktar M, Otlu B et al. An outbreak of Pseudomonas aeruginosa because of inadequate disinfection procedures in a urology unit: a pulsed-field gel electrophoresis-based epidemiologic study. Am J Infect Control 2008; 36: 33-38

20 Bou R, Aguilar A, Perpinan J et al. Nosocomial outbreak of Pseudomonas aeruginosa infections related to a flexible bronchoscope. J Hosp Infect 2006; 64: 129-135

21 Silva CV, Magalhaes VD, Pereira CR et al. Pseudo-outbreak of Pseudomonas aeruginosa and Serratia marcescens related to bronchoscopes. Infect Control Hosp Epidemiol 2003; 24: 195-197
22 Fraser TG, Reiner S, Malczynski M et al. Multidrug-resistant Pseudomonas aeruginosa cholangitis after endoscopic retrograde cholangiopancreatography: failure of routine endoscope cultures to prevent an outbreak. Infect Control Hosp Epidemiol 2004; 25: 856-859

23 Koo VS, O'Neill P, Elves A. Multidrug-resistant NDM-1 Klebsiella outbreak and infection control in endoscopic urology. BJU Int 2012; 110: E922 - E926

24 Carbonne A, Thiolet JM, Fournier S et al. Control of a multi-hospital outbreak of KPC-producing Klebsiella pneumoniae type 2 in France, September to October 2009. Euro Surveill 2010; 15:

25 Aumeran C, Poincloux L, Souweine B et al. Multidrug-resistant Klebsiella pneumoniae outbreak after endoscopic retrograde cholangiopancreatography. Endoscopy 2010; 42: 895-899

26 Lo Passo C, Pernice I, Celeste A et al. Transmission of Trichosporon asahii oesophagitis by a contaminated endoscope. Mycoses 2001; 44: $13-21$

27 Chang CL, Su LH, Lu CM et al. Outbreak of ertapenem-resistant Enterobacter cloacae urinary tract infections due to a contaminated ureteroscope. J Hosp Infect 2013; 85: 118-124

28 Bajolet 0 , Ciocan D, Vallet $C$ et al. Gastroscopy-associated transmission of extended-spectrum beta-lactamase-producing Pseudomonas aeruginosa. J Hosp Infect 2013; 83: 341 - 343

29 Mansour W, Bouallegue O, Said $\mathrm{H}$ et al. Outbreak of Pseudomonas aeruginosa infections associated with contaminated water in a university hospital in Tunisia. Infect Control Hosp Epidemiol 2008; 29: 378-380

30 Schelenz S, French G. An outbreak of multidrug-resistant Pseudomonas aeruginosa infection associated with contamination of bronchoscopes and an endoscope washer-disinfector. J Hosp Infect 2000; 46: 23-30

31 Shimono N, Takuma T, Tsuchimochi $N$ et al. An outbreak of Pseudomonas aeruginosa infections following thoracic surgeries occurring via the contamination of bronchoscopes and an automatic endoscope reprocessor. J Infect Chemother 2008; 14: 418-423

32 Alrabaa SF, Nguyen P, Sanderson R et al. Early identification and control of carbapenemase-producing Klebsiella pneumoniae, originating from contaminated endoscopic equipment. Am J Infect Control 2013; 41: $562-564$

33 Epstein L, Hunter JC, Arwady MA et al. New Delhi metallo-beta-lactamase-producing carbapenem-resistant Escherichia coli associated with exposure to duodenoscopes. JAMA 2014; 312: 1447-1455

34 Kressel AB, Kidd F. Pseudo-outbreak of Mycobacterium chelonae and Methylobacterium mesophilicum caused by contamination of an automated endoscopy washer. Infect Control Hosp Epidemiol 2001; 22: 414-418 DOI 10.1086/501926

35 Larson JL, Lambert L, Stricof RL et al. Potential nosocomial exposure to Mycobacterium tuberculosis from a bronchoscope. Infect Control Hosp Epidemiol 2003; 24: 825-830

36 Rosengarten D, Block C, Hidalgo-Grass $C$ et al. Cluster of pseudoinfections with Burkholderia cepacia associated with a contaminated washer-disinfector in a bronchoscopy unit. Infect Control Hosp Epidemiol 2010; 31: 769-771

37 Chroneou A, Zimmerman SK, Cook S et al. Molecular typing of Mycobacterium chelonae isolates from a pseudo-outbreak involving an automated bronchoscope washer. Infect Control Hosp Epidemiol 2008; 29: 1088 -1090 DOI 10.1086/591451

38 Sorin M, Segal-Maurer S, Mariano N et al. Nosocomial transmission of imipenem-resistant Pseudomonas aeruginosa following bronchoscopy associated with improper connection to the Steris System 1 processor. Infect Control Hosp Epidemiol 2001; 22: 409-413

39 Vanhems $P$, Gayet-Ageron A, Ponchon T et al. Follow-up and management of patients exposed to a flawed automated endoscope washerdisinfector in a digestive diseases unit. Infect Control Hosp Epidemiol 2006; 27: 89-92

40 Mean $M$, Mallaret MR, Bichard $P$ et al. Gastrointestinal endoscopes cleaned without detergent substance following an automated endoscope washer/disinfector dysfunction. Gastroenterol Clin Biol 2006; 30: $665-668$

41 Bisset $L$, Cossart YE, Selby $W$ et al. A prospective study of the efficacy of routine decontamination for gastrointestinal endoscopes and the risk factors for failure. Am J Infect Control 2006; 34: 274-280

42 Osborne S, Reynolds S, George $N$ et al. Challenging endoscopy reprocessing guidelines: a prospective study investigating the safe shelf life of flexible endoscopes in a tertiary gastroenterology unit. Endoscopy 2007; 39: 825-830

43 Ofstead CL, Wetzler HP, Snyder AK et al. Endoscope reprocessing methods: a prospective study on the impact of human factors and automation. Gastroenterol Nurs 2010; 33: 304-311 
44 Banerjee S, Shen B et al. Asge Standards Of Practice C. Infection control during GI endoscopy. Gastrointest Endosc 2008; 67: 781 -790 DOI 10.1016/j.gie.2008.01.027

45 Society of Gastroenterology N, Associates I. Standards of infection control in reprocessing of flexible gastrointestinal endoscopes. Gastroenterol Nurs 2006; 29: 142-148

46 Alvarado CJ, Reichelderfer $M$. APIC guideline for infection prevention and control in flexible endoscopy. Association for Professionals in Infection Control. Am J Infect Control 2000; 28: 138 - 155

47 Alfa MJ, Fatima I, Olson N. The adenosine triphosphate test is a rapid and reliable audit tool to assess manual cleaning adequacy of flexible endoscope channels. Am J Infect Control 2013; 41: 249-253

48 Alfa MJ, Olson N, Degagne P et al. Development and validation of rapid use scope test strips to determine the efficacy of manual cleaning for flexible endoscope channels. Am J Infect Control 2012; 40: 860 - 865

49 Cornelius MJ. FDA guidelines for endoscope reprocessing. Gastrointest Endosc Clin N Am 2000; 10: 259-264

50 Cooke RP, Whymant-Morris A, Umasankar RS et al. Bacteria-free water for automatic washer-disinfectors: an impossible dream? J Hosp Infect 1998; 39: $63-65$
51 [Anonymous] Cleaning and disinfection of equipment for gastrointestinal endoscopy. Report of a Working Party of the British Society of Gastroenterology Endoscopy Committee. Gut 1998; 42: 585 - 593

52 Instiut KfKuIbRK. Anforderungen der Hygiene bei der Aufbereitung flexibler Endoskope und endoskopischen Zusatzinstrumentariums. Bundesgesundheitsblatt Gesundheitsforschung Gesundheitsschutz 2002; 45: 17

53 Desinfectie SFERe. Kwaliteitshandboek Reiniging en Desinfectie Flexibele Endoscopen Versie 3.0. 2013

54 A.E. C, Australia GSo, Australia GNSo. Infection Control in Endoscopy: Guidelines \& Clinical Update. 2nd: ed. Sydney: Gastroenterological Society of Australia; 2003

55 Dirlam Langlay AM, Ofstead CL, Mueller NJ et al. Reported gastrointestinal endoscope reprocessing lapses: the tip of the iceberg. Am J Infect Control 2013; 41: 1188-1194

56 Morris J, Duckworth GJ, Ridgway GL. Gastrointestinal endoscopy decontamination failure and the risk of transmission of blood-borne viruses: a review. J Hosp Infect 2006; 63: 1-13 